http://ejournal.upi.edu/index.php/jaz/ - e-mail: jurnal.zonasi@gmail.com dan jurnal_zonasi@upi.edu

DOI: http://10.17509/jaz.v2i1.15061

\title{
PROTEKSI RISIKO KEBAKARAN DI PERUMAHAN STUDI KASUS: PERUMAHAN BARU DI KELURAHAN CIGADUNG, BANDUNG
}

\author{
Article History: \\ First draft received: \\ 21 Januari 2019 \\ Revised: \\ 28 Januari 2019 \\ Accepted: \\ 31 Januari 2019 \\ Final proof received:

\section{Vika Haristianti ${ }^{1}$; Made Anggita Wahyudi Linggasani ${ }^{2}$;} \\ Stefani Natalia Sabatini ${ }^{3}$; Dadang Hartabela ${ }^{4}$ \\ ${ }^{1}$ Program Studi Desain Interior, Universitas Telkom, Bandung, Indonesia \\ Jalan Telekomunikasi No. 1 Kabupaten Bandung \\ ${ }^{2}$ Program Studi Arsitektur, Universitas Warmadewa, Denpasar, Indonesia \\ ${ }^{3}$ Program Studi Arsitektur, Universitas Kristen Duta Wacana, Yogyakarta, Indonesia \\ ${ }^{4}$ Program Studi Arsitektur, Universitas Bandar Lampung, Bandar Lampung, Indonesia \\ Email: haristiantivika@telkomuniversity.ac.id \\ linggasani@warmadewa.ac.id \\ stefanisabatini@staff.ukdw.ac.id \\ dadang.hartabela@ubl.ac.id
}

Print:

10 Februari 2019

Online

11 Februari 2019
Abstract: The city of Bandung is one city that often experiences fire risk. Based on data from the Bandung Fire Prevention and Management Office, in 2000-2010, there were 1,624 fires with around 773 cases (48\%) occurring in residential areas. Even though ideally, planned housing complexes should have been designed to be able to reduce losses to a minimum due to the risk of fire. This research is a comparison between the real conditions in the field and the application of government regulations or rules and other standards regarding building safety, especially regarding the planning or anticipation of fire disasters in housing in the Bandung area. The method of data collection is done in two stages. In the first stage the literature review was carried out on the risks and protection of fires, especially in residential buildings. After that, interviews were also conducted with the Bandung Fire Department. Then, the results of the literature review and interviews are formulated into variables for reference in the field survey assessment.

This study used a purposive random sampling method in new housing in the Cigadung subdistrict, North Bandung with consideration of the density of settlements, the number of new housing growing in the area and the fact that Cigadung is one of the 40 areas prone to fire disasters in Bandung. The analysis was carried out with a comparison between theory and field conditions. The survey results were concluded descriptively. The assessment will be carried out by looking at the rule application points with a range of numbers 1 to 6 . This number is obtained from six matters regulated in regulations relating to fire protection, namely access points, environmental arrangements, brand, green open space, fire water source, and extinguishing equipment. Based on the results of the analysis, it can be concluded as follows. The eligibility category is divided into 3, namely not fulfilling the requirements (1-2 points), sufficiently fulfilling the requirements (3-4 points) and already fulfilling the requirements (5-6 points).

Keywords: Protection; Fire Risk, New Development Housing.

Abstrak: Kota Bandung merupakan salah satu kota yang sering mengalami risiko kebakaran. Berdasarkan data Dinas Pencegahan dan Penanggulangan Kebakaran Kota Bandung, pada tahun 2000-2010, terjadi sebanyak 1.624 kebakaran dengan sekitar 773 kasus (48\%) terjadi di daerah perumahan. Padahal idealnya, kompleks perumahan terencana seharusnya telah didesain untuk mampu mengurangi seminimal mungkin kerugian akibat risiko kebakaran. Penelitian ini merupakan komparasi antara kondisi nyata di lapangan dan penerapan regulasi atau aturan pemerintah dan standar lainnya mengenai keselamatan bangunan, terutama mengenai perencanaan atau antisipasi bencana kebakaran pada perumahan di daerah Bandung. Metode pengumpulan data dilakukan dengan dua tahap. Pada tahap pertama kajian literatur dilakukan terhadap risiko dan proteksi kebakaran khususnya pada bangunan perumahan. Setelah itu dilakukan juga wawancara kepada pihak Dinas Pemadam Kebakaran Kota Bandung. Lalu, hasil dari kajian literatur dan wawancara dirumuskan menjadi variabel untuk acuan penilaian survei lapangan. 
Penelitian ini menggunakan metode sampling purposive random sampling pada perumahan baru di kelurahan Cigadung, Bandung Utara dengan pertimbangan padatnya permukiman, banyaknya perumahan baru yang tumbuh di daerah tersebut serta fakta bahwa Cigadung merupakan salah satu dari 40 area rawan bencana kebakaran di Kota Bandung. Analisis dilakukan dengan cara komparasi antara teori dan kondisi lapangan. Hasil survei disimpulkan secara deskriptif. Penilaian akan dilakukan dengan melihat poin aplikasi aturan dengan kisaran angka 1 hingga 6 . Angka ini diperoleh dari enam hal yang diatur dalam peraturan terkait proteksi kebakaran, yaitu jalur akses, penataan lingkungan, brandgang, ruang terbuka hijau, sumber air pemadam, dan alat pemadam. Berdasarkan hasil analisis, maka dapat disimpulkan sebagai berikut. Kategori pemenuhan syarat dibagi menjadi 3, yaitu belum memenuhi syarat (1-2 poin), cukup memenuhi syarat (3-4 poin) dan sudah memenuhi syarat (5-6 poin).

Kata Kunci: Proteksi; Risiko Kebakaran, Perumahan Baru.

\section{Pendahuluan}

Kota Bandung merupakan salah satu kota yang sering mengalami risiko kebakaran. Menurut BPS (Badan Pusat Statistik), pada tahun 2013, Kota Bandung mengalami peristiwa kebakaran sebanyak 105 kasus yaitu 69\% dari bencana alam secara keseluruhan. Menurut data yang diperoleh dari Dinas Kebakaran dan Penanggulangan Kebakaran Bandung (2015), pada tahun 2014, kasus kebakaran di Kota Bandung meningkat menjadi 162 kali yang berarti naik sebanyak 20,9\%. Pada September 2014, terjadi kebakaran di Kota Bandung sebanyak 34 kasus. Berdasarkan data-data tersebut, dapat diketahui bahwa kasus kebakaran di Kota Bandung merupakan hal yang memerlukan perhatian.

Beberapa tahun terakhir, kasus kebakaran di daerah pemukiman mengalami peningkatan dan menghasilkan kerugian yang tidak sedikit. Berdasarkan data Dinas Pencegahan dan Penanggulangan Kebakaran Kota Bandung, pada tahun 2000-2010, terjadi sebanyak 1.624 kebakaran dengan sekitar 773 kasus (48\%) terjadi di daerah perumahan. Selain itu, BPS Kota Bandung juga mencatat jumlah kasus kebakaran pada tahun 2013 di mana 63 (48\%) dari 131 kasus kebakaran terjadi di bangunan perumahan (residence: pemukiman). Adapun mengenai penyebab terjadinya kebakaran, Kepala Dinas Pemadam Kebakaran Kota Bandung, Ferdi Ligaswara pada tahun 2014 menjelaskan bahwa 95\% penyebab kebakaran di Bandung adalah akibat korsleting listrik. Sisanya, kebakaran itu disebabkan oleh kompor, rokok dan lampu.

Menurut wawancara kepada Mardi Uripto (2015), staf bidang pemadaman Dinas Pemadam Kebakaran Kota Bandung, jika dilihat dari penyebab kebakaran, daerah yang memiliki potensi untuk mengalami kebakaran adalah daerah yang paling banyak menggunakan energi, dalam hal ini listrik. Pembeda potensi kebakaran antara satu tempat dengan tempat lain adalah kondisi keberadaan tiga unsur utama penyebab kebakaran yang sering disebut sebagai fire triangle. Menurutnya, kebakaran tetap dapat terjadi di pemukiman terencana seperti kompleks perumahan. Hal ini dikarenakan perumahan terencana pun tetap memenuhi keberadaan tiga unsur fire triangle dan bahkan menggunakan listrik, salah satu sumber heat pada kebakaran, dengan jumlah tinggi. Selain itu, ia mengungkapkan bahwa perumahan terencana saat ini sering menggunakan portal dan polisi tidur yang menyulitkan akses pemadam. Sayangnya, Dinas Pemadam Kebakaran belum bersedia memberikan data kebakaran yang terjadi di perumahan pada tahun 2017 sehingga daerah dengan tingkat risiko kebakaran tinggi di perumahan belum dapat diketahui.

Kompleks perumahan terencana, idealnya, telah didesain sehingga dianggap mampu mengurangi seminimal mungkin kerugian akibat risiko kebakaran. Hal ini dikarenakan adanya aturan bahwa sebenarnya desain pembangunan perumahan juga memerlukan rekomendasi dari dinas kebakaran kota sebagai salah satu syarat izin membangun (wawancara dengan W. Taufik K., 2015). Dengan adanya kebakaran di kompleks perumahan yang bahkan menimbulkan korban jiwa, aplikasi aturan terkait proteksi terhadap kebakaran di kompleks perumahan perlu ditilik kembali.

Studi ini merupakan komparasi antara kondisi nyata di lapangan dan penerapan regulasi/aturan pemerintah dan standar lainnya mengenai keselamatan bangunan, terutama mengenai perencanaan/antisipasi bencana kebakaran di perumahan di daerah Bandung. Sampel penelitian dikhususkan di kelurahan Cigadung dengan pertimbangan padatnya permukiman dan banyaknya perumahan baru yang tumbuh di kawasan tersebut dan fakta bahwa Cigadung merupakan salah satu dari 40 area rawan bencana kebakaran di Bandung.

Perumahan yang dimaksud dalam studi ini adalah sekelompok rumah yang berfungsi sebagai lingkungan tempat tinggal, baik di perkotaan dan perdesaan yang dilengkapi dengan prasarana dan sarana lingkungan sebagai hasil upaya pemenuhan rumah yang layak huni, termasuk di dalamnya adalah komplek perumahan. Tujuan dari studi ini adalah mengetahui potensi kebakaran pada perumahan terencana yang baru dibangun terkait kesesuaiannya dengan aturan yang berlaku. Secara lebih rinci dalam penelitian ini dilakukan 
penilaian terhadap enam poin pemenuhan aspek proteksi aktif dan pasif terhadap risiko kebakaran, yaitu persyaratan-persyaratan mengenai Jalur Akses (JA), Penataan Lingkungan (PL), Brandgang (BG), Ruang Terbuka Hijau (RTH), Sumber Air Pemadam (SAP), dan Alat Pemadam (AP). Manfaat studi ini adalah untuk menunjukkan aplikasi penerapan aturan pemerintah pada pembangunan di lapangan dan meningkatkan keawasan masyarakat mengenai hal-hal yang terkait dengan proteksi kebakaran. Adapun dasar dari pemikiran terangkum pada hasil studi literatur di bawah ini:

\subsection{Proteksi Kebakaran}

"Kebakaran adalah adanya api yang tidak dikehendaki" (Suprapto, 2008). Menurut Wawan Sungkawa (wawancara 2015), staf bidang penyuluhan Dinas Pemadam Kebakaran Kota Bandung, selain tidak dikehendaki, api yang digolongkan kebakaran adalah saat keberadaannya cenderung memberikan kerugian. Menurutnya, selama api tidak menimbulkan kerugian, maka api tak perlu disebut sebagai risiko kebakaran. Ia menambahkan bahwa risiko adalah sesuatu yang dapat diprediksi, diantisipasi, dan diminimalisasi. Serangkaian usaha, yaitu proteksi kebakaran, dapat dilakukan untuk mengurangi risiko kebakaran ini.

Upaya proteksi kebakaran, menurut Mantra (2005), dibagi menjadi proteksi pasif, proteksi aktif, dan fire safety management. Proteksi pasif, menurutnya, adalah melalui desain bangunan yaitu meliputi desain site plan dan lingkungan bangunannya, struktur yang tahan api, sarana penyelamatan jiwa, dan pemilihan bahan bangunan yang digunakan. Proteksi aktif adalah ketersediaan alat-alat bantu pendeteksian dan pemadaman api seperti komponen fire hydrant, fire extinguisher (APAR, Alat Pemadam Api Ringan), dan lain-lain yang sesuai dengan standar keamanan. Proteksi pasif dan aktif perlu disingkronkan dan dikendalikan bersama dengan unsur manusia/personil, sistem dan peralatan, informasi, dan data teknis, serta kelengkapan lainnya dalam satu upaya dengan tujuan pengurangan dampak bencana. Pengendalian ini disebut fire safety management.

\subsection{Faktor Risiko Kebakaran}

Risiko kebakaran yang kemudian mampu menimbulkan kerugian dapat disebabkan oleh beberapa faktor. Simanjuntak, melalui tulisan mengenai penelitiannya di perumahan dan pemukiman di DKI Jakarta, menyebutkan beberapa faktor risiko kebakaran di dalam desain perumahan dan pemukiman seperti ditampilkan melalui Tabel 2.1 Faktor yang disebutkannya dibagi dalam tiga tipe yaitu faktor risiko pada proteksi aktif, proteksi pasif, dan manajemen penanggulangan kebakaran.

Tabel 1. 1 Faktor Risiko Kebakaran Dalam Desain Perumahan dan Permukiman

(Sumber: Simanjuntak, M.R Adventus. Desain Keselamatan Terhadap Risiko Kebakaran (Fire Safety Environtment Area) pada Lingkungan Perumahan \& Permukiman di DKI Jakarta)

\subsection{Klasifikasi Kebakaran Menurut Jenis Bahanya}

Klasifikasi kebakaran adalah penggolongan atau pembagian kebakaran atas dasar jenis bahan bakarnya. Pengklasifikasian ini bertujuan untuk memudahkan usaha pencegahan dan pemadaman kebakaran 
(Soehatman Ramli, 2005). NFPA (National Fire Protection Association) adalah suatu lembaga swasta yang khusus menangani di bidang penanggulangan bahaya kebakaran di Amerika Serikat. Menurut NFPA, kebakaran dapat diklasifikasikan menjadi 4 kelas; kelas A, yaitu kebakaran bahan padat kecuali logam, kelas B, yaitu kebakaran bahan cair dan gas yang mudah terbakar, kelas C, yaitu kebakaran listrik yang bertegangan, dan kelas D, yaitu kebakaran bahan logam. Hal ini sama dengan yang disampaikan dalam Keputusan Walikota Bandung nomor 1484 tahun 2003 pada Bagian Ketiga, paragraf pertama pasal 7 ayat (2).

Melihat hal ini, perumahan terencana, secara umum, dapat digolongkan ke dalam klasifikasi kebakaran kelas A. Aturan di Bandung menggolongkan hunian, bersama ruang kantor, ruang kelas, dan ruang pertemuan, ke dalam kelas A saja, sebagai klasifikasi bahaya ringan, karena keberadaan perabot, dekorasi, dan isi ruangannya sesuai dengan bahan pada kebakaran kelas A. Kelas A adalah kebakaran bahan padat kecuali logam. Unsur bahan yang terbakar biasanya mengandung karbon, yaitu kertas, kayu, tekstil, plastik, karet, busa, dan bahan lainnya. Aplikasi media pemadam yang cocok pada kebakaran kelas A ialah bahan jenis basah yaitu air.

Meskipun begitu, hunian sebenarnya memiliki penggunaan gas bumi (seperti pada kelas B, sebagai klasifikasi bahaya sedang, yaitu seperti pada ruang makan, tempat bejualan, tempat parkir, dan gudang) dan listrik bersama peralatan rumah tangga, trafo, komputer, televisi, radio, panel listrik, transmisi listrik, dan lainnya (seperti pada kelas C). Meskipun begitu, dikarenakan kurangnya dasar yang lebih jelas untuk mengelompokkan kelas-kelas ini, seperti persentase bahan misalnya sebagai dasar, maka keberadaan elpigi dan listrik dianggap langsung berimplikasi terhadap perubahan kelas kebakaran hunian dari hanya A saja menjadi juga $\mathrm{B}$ dan $\mathrm{C}$.

\subsection{Peraturan Pemerintah Terkait Proteksi Risiko Kebakaran Di Perumahan}

Pemerintah menyadari pentingnya proteksi risiko kebakaran di perumahan dan membuat beberapa peraturan terkait hal-hal yang dapat dilakukan untuk mengurangi dampak bencana kebakaran. Meskipun begitu, tak semua dari peraturan terkait proteksi kebakaran itu mencantumkan aturan yang khusus diberlakukan bagi bangunan perumahan, dalam konteks ini adalah landed housing. Aturan yang bersifat nasional mengenai proteksi risiko kebakaran di perumahan di Indonesia antara lain adalah;

a. Penjelasan Undang-Undang Republik Indonesia Nomor 4 tahun 1992

b. Keputusan Menteri Negara Pekerjaan Umum Nomor 10/KPTS/2000

c. Peraturan Menteri Pekerjaan Umum Nomor: 26/PRT/M/2008 tanggal 30 Desember 2008

d. Peraturan Daerah Kota Bandung nomor 07 tahun 2013

Sebagai contoh, pemerintah telah mengatur mengenai akses mobil pemadam kebakaran di lingkungan perumahan dalam Permen PU No.26 Tahun 2008. Di sana disebutkan bahwa untuk ketinggian bangunan kurang dari $10 \mathrm{~m}$ wajib memiliki jalur akses mobil pemadam kebakaran dengan lebar bidang kerja minimum $4 \mathrm{~m}$ dan panjang bidang kerja maksimum 45 meter. Lebar jalan/perkerasan minimal $4 \mathrm{~m}$ dengan memiliki ruang untuk mobil pemadam kebakaran beroperasi $6 \mathrm{~m} \mathrm{x} 15 \mathrm{~m}$. Sebagai catatan, tanaman dan pohon antara bangunan dan jalan akses tidak mengganggu proses pemadaman ketika terjadi kebakaran. Jangkauan mobil pemadam kebarakan wajib mengikuti peraturan seperti yang dicontohkan. Pada Gambar 1.1 di bawah ini:

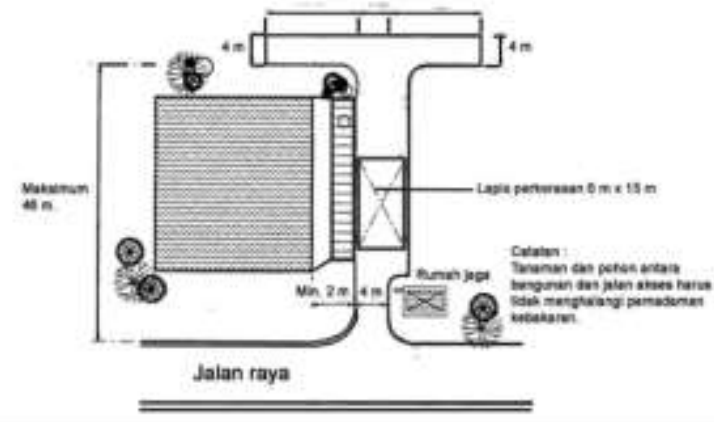

Gambar 1. 1 Akses jalan untuk mobil pemadam pada hunian

(Sumber: Permen PU No. 26 Tahun 2008)

Pemerintah Bandung sendiri, secara khusus, telah membuat peraturan tentang proteksi risiko kebakaran bangunan di Bandung yang di dalamnya juga mencakup tentang aturan bagi perumahan. Aturan yang lama adalah Peraturan Daerah Kota Bandung Nomor 15 tahun 2001 tentang Pencegahan dan Penanggulangan Bahaya Kebakaran. Aturan ini kemudian dijabarkan dengan lebih jelas melalui Keputusan Walikota Bandung nomor 23 tahun 2003 tentang Petunjuk Pelaksanaan Pencegahan dan Penanggulangan Bahaya Kebakaran. Pada tahun 2012, Perda Bandung nomor 15 tahun 2001 ini dicabut dan kemudian diperbarui dengan Perda yang baru yaitu Peraturan Daerah Kota Bandung nomor 12 tahun 2012 tentang Pencegahan, Penanggulangan Bahaya Kebakaran dan Retribusi Pemeriksaan Alat Pemadam Kebakaran. 
Pada Perda Bandung nomor 12 tahun 2012 ini, bab XXII pasal 81, disebutkan bahwa Peraturan Pelaksanaan Peraturan Daerah ini harus ditetapkan paling lama satu tahun sejak Perda ini diundangkan. Nyatanya, hingga tahun 2015 ini, Keputusan Walikota Bandung mengenai Peraturan Pelaksanaan dari Peraturan Daerah nomor 12 tahun 2012 ini belum diterbitkan.

Peraturan Daerah Kota Bandung Nomor 15 tahun 2001 tetap diacu namun tidak diutamakan karena telah dicabut keberlakuannya. Begitu pula Keputusan Walikota Bandung nomor 23 tahun 2003 tetap diacu karena peraturan pelaksanaan dari Peraturan Daerah nomor 12 tahun 2012 ini belum diterbitkan. Dalam analisis ini, dapat ditunjukkan bahwa peraturan yang berlaku di Bandung, banyak mengatur pada proteksi secara pasif dan aktif namun kurang pada manajemen penanggulangan kebakaran lingkungan.

\section{Metode Penelitian}

Metode pengumpulan data dilakukan dengan dua tahap. Pada tahap pertama kajian literatur dilakukan terhadap risiko dan proteksi kebakaran khususnya pada bangunan perumahan. Acuan yang diambil adalah dari jurnal, tulisan terkait dan peraturan yang berlaku. Setelah itu wawancara juga dilakukan kepada pihak Dinas Pemadam Kebakaran Kota Bandung. Hasil dari kajian literatur dan wawancara dirumuskan menjadi variabel untuk acuan penilaian survei lapangan.

Metode sampling yang digunakan adalah purposive random sampling pada perumahan baru (new development) di Kelurahan Cigadung, Bandung Utara. Alasan pemilihan Kelurahan Cigadung sebagai lokasi pengambilan sampel adalah karena kelurahan ini masuk dalam daftar daerah rawan bencana kebakaran menurut Dinas Kebakaran Kota Bandung. Perumahan new development sendiri dipilih agar informasi teknis (data site plan, luasan, denah, penjelasan fasilitas, dll) yang didapat dari pihak developer dan pemasaran dapat lebih jelas dan lengkap sehingga memudahkan proses penilaian saat survei.

Analisis dilakukan dengan komparasi antara teori dan kondisi lapangan. Hasil survei disimpulkan secara deskriptif. Dari data tersebut, akan dilihat bagaimana kondisi proteksi risiko kebakaran di perumahan tersebut. Penilaian akan dilakukan dengan melihat poin aplikasi aturan dengan kisaran angka 1 hingga 6 . Angka ini diperoleh dari enam hal yang diatur dalam peraturan terkait proteksi kebakaran, yaitu jalur akses, penataan.

\section{Hasil dan Pembahasan}

Penilaian dilakukan kepada masing-masing perumahan sesuai poin yang ada pada Tabel V.1 di kolom kesimpulan. Pada bagian ini, hasil tersebut akan diuraikan per perumahan. Adapun keterangan lokasi dan siteplan dari studi kasus akan dijabarkan pada Tabel 3.1 di bawah ini:

Tabel 3. 1 Data Studi Kasus

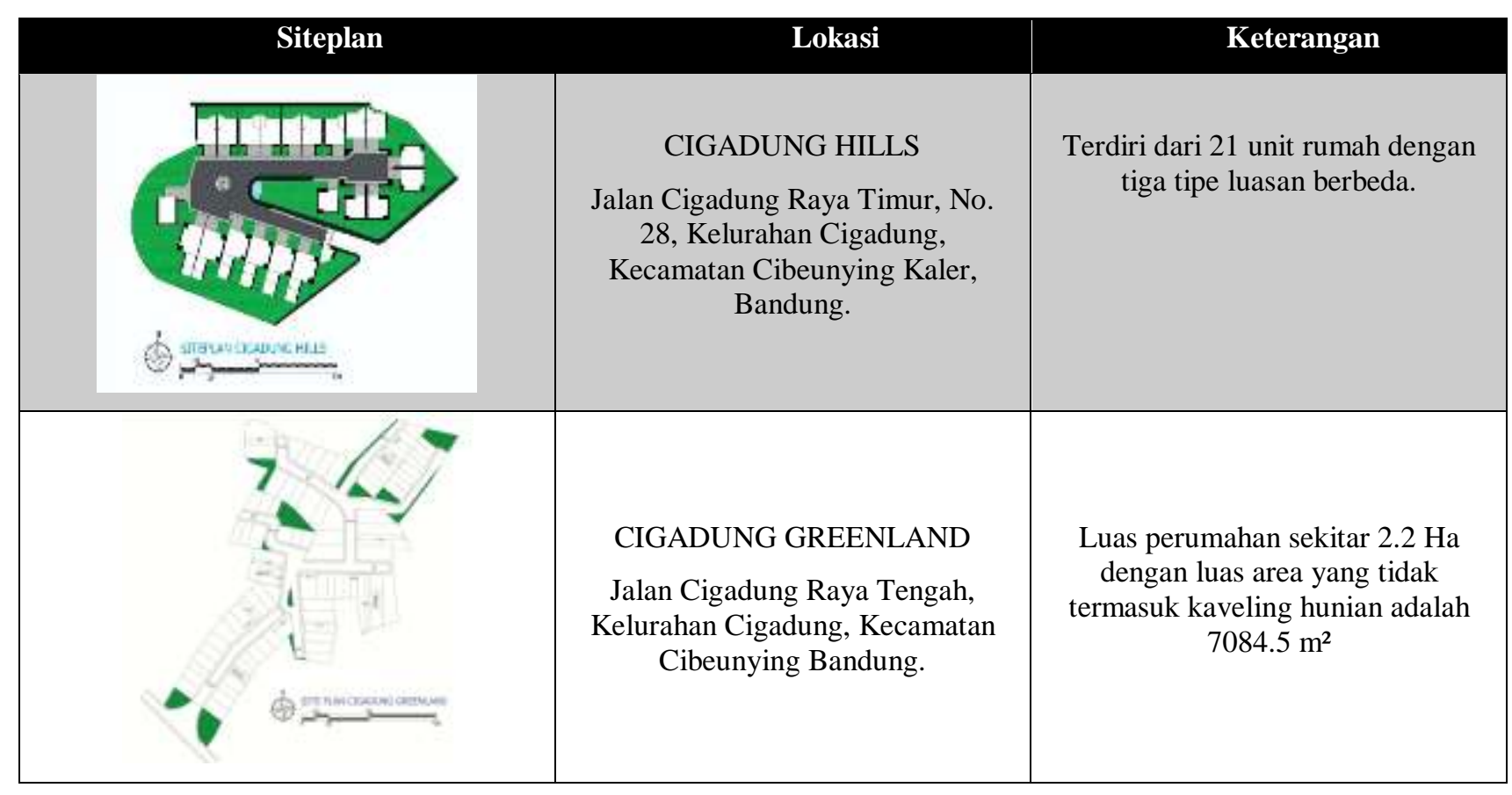




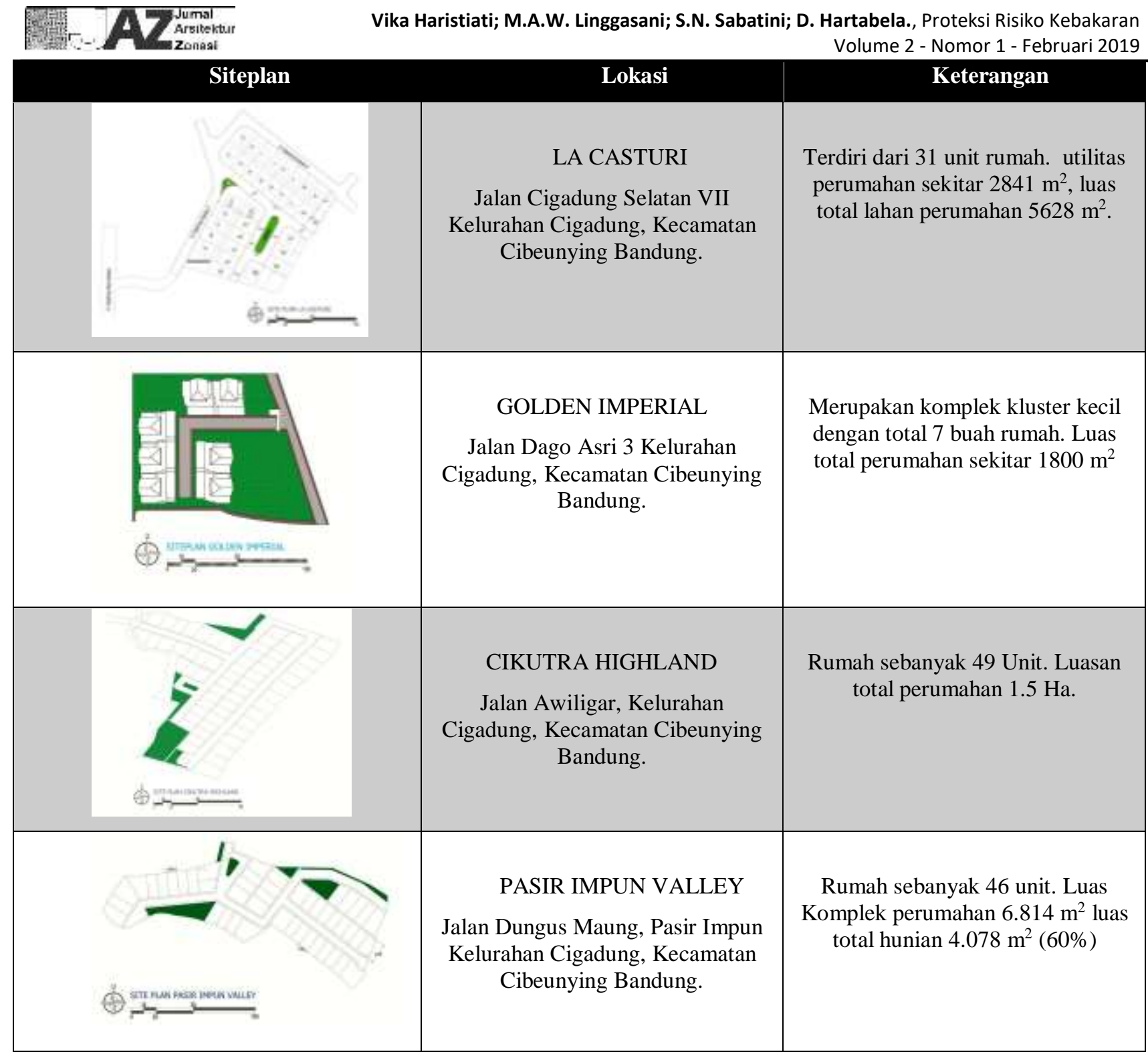

(Sumber: Penulis, 2017)

\subsection{Perumahan Cigadung Hills}

Perumahan ini tidak memiliki alat pemadam kebakaran berupa hydrant. Lebar jalan lingkungan perumahan ini sekitar 6 - 9 meter sehingga memungkinkan mobil pemadam kebakaran mengakses lokasi. Namun begitu, keberadaan portal dengan sistem satu pintu dapat mengganggu pencapaian mobil kebakaran sebab kondisi tersebut mengurangi kecepatan mobil kebakaran menuju proses pemadaman api. Akses terhadap jalan utama (Jl. Cigadung) sangat dekat namun lebar jalan hanya sekitar 6 meter sehingga jika ada mobil kebakaran dan mobil lain dari arah berlawanan akan menyulitkan dan berdampak memakan waktu lebih lama lagi untuk sampai ke lokasi. Secara keseluruhan terdapat 21 rumah dengan tiga tipe berbeda di perumahan ini. Ketinggian bangunan adalah satu hingga dua lantai. Material rumah menggunakan bahan yang tergolong modern. Perkerasan jalan menggunakan aspal dengan paving block di bagian tepi jalan di sepanjang kompleks.

Ditinjau dari material yang terdapat dalam rumah, bangunan dapat diklasifikasikan kedalam risiko kebakaran kelas A (kebakaran yang terjadi pada bahan-bahan mudah terbakar yang biasa terdapat pada rumah tangga, seperti kayu, kain, kertas, karet dan plastik), kelas B (kebakaran yang melibatkan bahan cair dan gas yang mudah terbakar), serta kelas $\mathrm{C}$ (kebakaran yang melibatkan peralatan listrik pada kondisi aliran listrik hidup). Instalasi listrik perumahan menggunakan jalur bawah tanah. Galian penampungan air sendiri disimpan di bagian depan rumah untuk memudahkan perawatan oleh pihak pengguna dan pengelola. Rumah di Cigadung Hills masuk kedalam kategori terrace house dimana setiap rumah bergandengan di bagian kanan dan kiri. Brandgang tidak terdapat di sini dan memang tidak disyaratkan keberadaannya. Tinggi bangunan sendiri sudah sesuai sekitar 4-8m. Ditinjau dari segi pencegahan pasif, pihak developer tidak memasang sprinkler atau alarm kebakaran didalam setiap rumah. Pemantauan dilakukan melalui Televisi Sirkuit Tertutup (Closed Circuit Television/ CCTV) yang berpusat di pos keamanan bagian depan kompleks. 
Keberadaan APAR 2A disetiap rumah tidak terpenuhi karena belum adanya sosialisasi dari pemerintah dan dinas kebakaran akhirnya mengakibatkan masyarakat awam tidak mengetahui perlunya pencegahan berupa kepemilikan APAR dirumah. Keberadaan ruang hijau perumahan sudah terpenuhi dimana luasan lebih dari $40 \%$ luas total kompleks perumahan secara keseluruhan.

Dari segi proteksi pasif, variabel penilaian terisi dengan hasil memenuhi standar. Material bangunan dan volume bangunan sesuai dengan aturan, begitupun dengan lebar jalan, letak akses bangunan, perkerasan jalan, akses keluar bangunan, dan kemudahan akses lokasi oleh pemadam. Hanya saja, sama seperti pada model kompleks perumahan lainnya, Cigadung Hills memiliki portal yang dapat menghambat mobil pemadam sampai ke dalam. Kelemahan lain dari lokasi perumahan ini adalah sempitnya lebar jalur utama di depan kompleks yang akan sedikit menyulitkan mobil pemadam untuk sampai.

Dilihat dari proteksi aktif, sistem listrik bawah tanah dinilai aman oleh pengembang dan tim pemasaran. Warga perumahan sendiri belum memiliki pengetahuan untuk menyiapkan APAR di rumahnya. Rata-rata masyarakat memiliki jawaban yang sama bahwa tidak adanya sosialisasi dari pemerintah dan dinas kebakaran menyebabkan mereka tidak mengetahui hal tersebut. Keberadaan sprinkler dan alarm kebakaran yang tidak terdapat di kompleks perumahan ini tidak menjadi masalah karena berdasarkan luasan dan tinggi rumah yang ada, perumahan ini tidak diharuskan memiliki alat tersebut. CCTV yang berpusat di pos satpam dinilai sudah cukup untuk memenuhi proteksi pasif. Perumahan Cigadung Hills tidak memiliki persyaratan yang tidak terpenuhi kecuali keberadaan APAR disetiap hunian. Kesulitan terbesar terdapat pada lebar jalan dan portal saja karena dapat menghambat jalannya mobil pemadam kebakaran.

\subsection{Perumahan Cigadung Greenland}

Pada papan pembangunan di depan perumahan tertulis bahwa lebar jalan adalah $12 \mathrm{~m}$ dan GSB-nya adalah $6 \mathrm{~m}$. Setiap rumah direncanakan menjadi bangunan dua lantai. bahwa luasan kaveling hunian di perumahan ini cukup bervariasi dari sekitar $100 \mathrm{~m}^{2}$ hingga sekitar $370 \mathrm{~m}^{2}$. Ukuran kavelingnya pun bervariasi; panjang muka kalping mulai dari sekitar $5.5 \mathrm{~m}$ hingga $15 \mathrm{~m}$ sedangkan panjang ke dalam tapaknya mulai dari sekitar $17 \mathrm{~m}$ hingga sekitar $45 \mathrm{~m}$. Meskipun perumahan ini berada di pinggir jalan lingkungan secara langsung, namun jarak rumah terjauh di perumahan ini menuju jalan lingkungan adalah sekitar $300 \mathrm{~m}$. Luas perumahan ini adalah sekitar 2.2 ha dengan luas area yang tidak termasuk kaveling hunian adalah $7084.5 \mathrm{~m}^{2}$.

Dari sisi proteksi pasif, Perumahan Cigadung Greenland cukup baik dan memenuhi persyaratan. Perumahan ini termasuk risiko kebakaran kelas A, Kelas B dan Kelas C. Jalur akses yang dimiliki juga telah memiliki luasan, kebebasan dari hambatan, dan perkerasan yang cukup. Penataan lingkungan dan bangunan cukup baik meskipun letak perumahan cukup jauh dari jalan utama yang mudah dilalui pemadam.

Dari sisi proteksi aktif, data yang diperoleh dari perumahan ini belum cukup untuk dibahas. Perumahan ini menggunakan sumur-sumur pribadi di masing-masing kaveling untuk memenuhi kebutuhan airnya. Air kemudian ditampung di tandon-tandon air di bagian paling atas dari rumah untuk didistribusikan. Kemudahan pasukan pemadam untuk mengakses air-air ini belum diketahui. Tidak terdapat sumber air pemadam lain yang dapat digunakan di perumahan ini.

Dari sisi proteksi pasif, perumahan ini tidak memiliki brandgang padahal berdasarkan luasannya, perumahan ini diwajibkan memiliki brandgang. Hal ini dimungkinkan karena belum jelasnya aplikasi peraturan tentang brandgang yang diterbitkan pada tahun 2012 dan hingga kini belum diterbitkan penjelasan melalui Peraturan Walikota-nya. Aplikasi peraturan tentang jarak bangunan juga belum dapat teramati dengan baik. Persyaratan yang tidak terpenuhi adalah tentang luasan utilitas minimum perumahan. Standar luasan utilitas minimum perumahan adalah $40 \%$ sedangkan luasan utilitas perumahan ini adalah $31 \%$ atau kurang dari $40 \%$.

Pada proteksi aktif, berdasarkan jarak terjauh rumah di perumahan ini terhadap jalan lingkungan, seharusnya perumahan ini memiliki hydrant tersendiri namun nyatanya tidak. Keberadaan APAR di tiap unit rumah. Keberadaan unit pompa dan tangki penampungan air di RW di mana perumahan ini berada belum diketahui. Berdasarkan tinggi bangunannya, hunian di perumahan ini tidak wajib memiliki alarm kebakaran maupun sprinkler.

\subsection{Perumahan La Casturi}

Perumahan ini berlokasi di Jalan Cigadung Selatan VII. Jumlah rumah terbangun adalah sebanyak 31 unit namun saat ini baru terbangun 24 unit. Ditinjau dari bahan-bahan yang ada di perumahan ini maka perumahan ini dapat diklasifikasikan ke dalam risiko kebakaran kelas A, kelas B dan kelas C sebab di dalam area perumahan ini terdapat bahan-bahan kombustibel seperti kayu, kain, kertas, karet dan plastik dan bahanbahan cair seperti minyak dan gas yang mudah terbakar, serta peralatan listrik. Sumber air pada kawasan perumahan ini keseluruhannya berasal dari PDAM yang dialirkan ke tandon-tandon air masing-masing unit rumah. Dalam satu perumahan terdapat TIGA sumur bor dengan menggunakan pompa (jet pump) yang dapat 
digunakan sebagai sumber air untuk pemadaman. Secara menyeluruh perumahan La Casturi ini memenuhi sebagian besar syarat (pasif dan aktif) yang harus dipenuhi. Yaitu syarat mengenai penataan lingkungan, akses bangunan, dan ruang terbuka. Sedangkan syarat yang tidak terpenuhi adaah keberadaan brandgang dan instalasi hydrant. Maka dapat disimpulkan bahwa perumahan ini cukup memenuhi syarat proteksi kebakaran.

\subsection{Perumahan Golden Imperial}

Terdiri dari tujuh unit rumah, sumber air pada kawasan perumahan ini keseluruhannya berasal dari PDAM yang dialirkan ke tandon-tandon air masing-masing unit rumah. Ditinjau dari bahan-bahan yang ada di perumahan ini, maka perumahan ini dapat diklasifikasikan kedalam risiko kebakaran kelas A, kelas B dan kelas C.

Penataan lingkungan dan bangunan cukup baik dan letak perumahan dekat dengan jalan utama sehingga mudah dilalui oleh mobil pemadam kebakaran. Kondisi perkerasannya cukup baik dengan bahan perkerasan berupa aspal dan tidak adanya hambatan berupa polisi tidur. Meski begitu, keberadaan portal pada akses keluar masuk yang terletak di arah timur perumahan dapat mengganggu proses pencapaian mobil dalam memadamkan kebakaran. Luas permukaan area utilitas perumahan sekitar $700 \mathrm{~m}^{2}$, sedangkan luas total lahan perumahan sekitar $1800 \mathrm{~m}^{2}$. Dengan luasnya yang kurang dari $5000 \mathrm{~m}^{2}$, maka perumahan ini tidak diwajibkan memiliki ruang terbuka hijau. Perumahan ini juga tidak memiliki brandgang. Berdasarkan luasnya $\left(<5000 \mathrm{~m}^{2}\right)$ perumahan ini memang tidak wajib memiliki brandgang.

Jalur akses yang dimiliki cukup sempit yaitu 3,5 sampai 5,5 m sehingga agak sulit dilalui mobil pemadam kebakaran. Peraturan Menteri No.26 Tahun 2008 menyaratkan lebar akses masuk minimal 4 m. Sehingga perumahan ini tidak memenuhi syarat proteksi kebakaran jika dinilai dari jalur akses masuk. Selain itu, perumahan ini tidak memiliki instalasi hydrant yang dapat digunakan untuk membantu mempercepat proses pemadaman apabila terjadi kebakaran di kawasan tersebut. Secara menyeluruh perumahan Golden Imperial memenuhi syarat (pasif dan aktif) mengenai posisi bangunan dari jalan lingkungan. Namun, lebar akses masuk dan keberadaan hydrant tidak memenuhi syarat proteksi kebakaran. Maka dapat disimpulkan bahwa perumahan ini cukup memenuhi syarat proteksi kebakaran.

\subsection{Perumahan Cikutra Highland}

Komplek perumahan seluas 1,5 Ha ini menggunakan sistem sirkulasi kuldesak. Sumber air pada kawasan perumahan ini keseluruhannya berasal dari sumur dangkal sedalam 12 meter di dataran tinggi yang dialirkan melalui pipa artesis ke tandon-tandon air masing-masing unit rumah. Ditinjau dari bahan-bahan yang ada di perumahan ini, maka dapat diklasifikasikan kedalam risiko kebakaran kelas A, kelas B dan kelas C. Sebab, di dalam area perumahan ini akan terdapat bahan-bahan kombustibel seperti kayu, kain, kertas, karet dan plastik, dan bahan-bahan cair seperti minyak dan gas yang mudah terbakar, serta peralatan listrik.

Perumahan ini direncanakan memiliki brandgang, berdasarkan luasnya (1,5 ha) perumahan ini memang wajib memiliki brandgang. Jalur akses yang dimiliki cukup luas yaitu enam hingga tujuh meter sehingga dapat dilalui mobil pemadam kebakaran. Kondisi perkerasannya cukup baik dengan bahan aspal dan tidak adanya hambatan berupa polisi tidur. Meski begitu, keberadaan portal pada akses keluar masuk yang terletak di arah timur kompleks dapat mengganggu proses pencapaian mobil dalam memadamkan kebakaran. Menurut perencanaan, perumahan ini akan memasang sebuah hydrant di tengah lokasi kompleks dengan air yang bersumber dari penampungan air utama kompleks.

Letak perumahan ini cukup jauh dari jalan utama yaitu 300 meter sehingga mobil pemadam kebakaran sulit menjangkaunya. Persyaratan yang tidak terpenuhi adalah tentang luasan utilitas minimum perumahan. Menurut rencana, luas permukaan yang tertutupi oleh perumahan adalah sekitar $12.000 \mathrm{~m}^{2}$ sedangkan luas total lahan perumahan sekitar $15.000 \mathrm{~m}^{2}$. Persentase luas lahan yang tertutupi adalah $80 \%$ sehingga luas ruang terbuka hanya sekitar 20\%, yaitu kurang dari $40 \%$. Oleh karena itu, perumahan ini tidak memenuhi syarat Proteksi Pasif tentang utilitas ruang terbuka sesuai peraturan dari pemerintah. Secara menyeluruh perumahan Cikutra Highland ini memenuhi syarat (pasif dan aktif) mengenai keberadaan brandgang, kondisi perkerasan, keberadaan hydrant, dan lebar akses untuk mobil pemadam kebakaran. Namun, letak perumahan yang sulit dijangkau dan luas ruang terbuka yang dimiliki tidak memenuhi syarat proteksi kebakaran. Maka dapat disimpulkan bahwa perumahan ini cukup memenuhi syarat proteksi kebakaran.

\subsection{Perumahan Pasir Impun Valley}

Komplek perumahan ini memiliki luas $6.814 \mathrm{~m}^{2}$ dengan luas total hunian $4.078 \mathrm{~m}^{2}(60 \%)$. Sumber air pada kawasan perumahan seluruhnya berasal dari mata air pegunungan yang dialirkan ke tandon besar melalui pipa sepanjang $4 \mathrm{~km}$. Ditinjau dari bahan-bahan yang ada di perumahan ini, maka dapat diklasifikasikan kedalam risiko kebakaran kelas A, kelas B dan kelas C sebab, di dalam area perumahan ini terdapat bahan-bahan kombustibel seperti kayu, kain, kertas, karet dan plastik, dan bahan-bahan cair seperti minyak dan gas yang mudah terbakar, serta peralatan listrik. 
Penataan lingkungan dan bangunan cukup baik dengan adanya beberapa titik penghijauan berupa taman. Letak perumahan cukup dekat dari jalan utama yaitu sekitar $30 \mathrm{~m}$, sehingga mudah dilalui oleh mobil pemadam kebakaran. Luas permukaan yang tertutupi oleh utilitas perumahan sekitar $4.078 \mathrm{~m}^{2}$, sedangkan luas total lahan perumahan sekitar $6.814 \mathrm{~m}^{2}$. Persentase luas lahan yang tertutupi adalah $60 \%$ sehingga luas ruang terbuka $40 \%$ yaitu sesuai dengan standar Proteksi Pasif tentang utilitas sesuai peraturan dari pemerintah. Jalur akses yang dimiliki cukup luas yaitu 4-5 m, sehingga cukup mudah dilalui mobil pemadam kebakaran. Kondisi perkerasannya cukup baik dengan bahan aspal dan tidak adanya hambatan berupa polisi tidur. Namun, Keberadaan portal pada akses keluar masuk mengganggu proses pencapaian mobil dalam memadamkan kebakaran.

Perumahan ini tidak memiliki instalasi hydrant yang dapat digunakan untuk membantu mempercepat proses pemadaman apabila terjadi kebakaran di kawasan tersebut. Selain itu, perumahan ini juga tidak memiliki brandgang, padahal berdasarkan luasnya (lebih dari $5000 \mathrm{~m}^{2}$ ) perumahan ini wajib memiliki brandgang. Sehingga perumahan ini tidak memenuhi syarat proteksi kebakaran pada aspek keberadaan brandgang. Sumber air yang berasal dari mata air pegunungan sangat bergantung pada kondisi pipa penyalur. Apabila terjadi kerusakan pada pipa tersebut, dikhawatirkan dapat mengganggu sistem pengairan di perumahan. Terlebih, apabila terjadi kebakaran, maka akan sangat sulit memperoleh air cadangan, apabila pipa tersebut rusak. Secara menyeluruh perumahan Pasir Impun Valley ini memenuhi syarat (pasif dan aktif) mengenai letak perumahan dari jalan utama, penataan lingkungan dan keberadaan ruang terbuka. Namun, persyaratan mengenai keberadaan brandgang dan sumber air tidak memenuhi syarat. Maka dapat disimpulkan bahwa perumahan ini cukup memenuhi syarat proteksi kebakaran.

\section{Kesimpulan}

Berdasarkan hasil analisis dari keenam objek perumahan pada bab sebelumnya, maka dapat disimpulkan sebagai berikut. Kategori pemenuhan syarat dibagi menjadi 3, yaitu belum memenuhi syarat (12 poin), cukup memenuhi syarat (3-4 poin) dan sudah memenuhi syarat (5-6 poin). Hasil analisis dapat dilihat pada Tabel 4.1 di bawah ini

Tabel 4. 1 Penilaian Pemenuhan Syarat Proteksi Kebakaran pada Perumahan yang Diteliti

\begin{tabular}{|c|c|c|c|c|c|c|c|c|}
\hline \multirow{2}{*}{$\begin{array}{c}\text { Objek } \\
\text { Perumahan }\end{array}$} & \multicolumn{4}{|c|}{ Pasif } & \multicolumn{2}{|c|}{ Aktif } & \multirow[t]{2}{*}{ Jumlah Poin } & \multirow[t]{2}{*}{ Kesimpulan } \\
\hline & $\mathbf{J A}$ & PL & BG & RTH & SAP & $\mathbf{A P}$ & & \\
\hline $\begin{array}{c}\text { Perumahan } \\
\text { Cigadung Hills }\end{array}$ & V & $\mathrm{V}$ & V & V & - & - & 4 & Cukup memenuhi syarat \\
\hline $\begin{array}{l}\text { Perumahan } \\
\text { La' Casturi }\end{array}$ & $\mathrm{v}$ & $\mathrm{v}$ & - & V & - & - & 3 & Cukup memenuhi syarat \\
\hline $\begin{array}{c}\text { Perumahan } \\
\text { Cigadung } \\
\text { Greenland }\end{array}$ & $\mathrm{V}$ & $\mathrm{V}$ & - & - & - & - & 2 & Belum memenuhi syarat \\
\hline $\begin{array}{c}\text { Perumahan } \\
\text { Golden } \\
\text { Imperial }\end{array}$ & - & $\mathrm{V}$ & V & $\mathrm{V}$ & - & - & 3 & Cukup memenuhi syarat \\
\hline $\begin{array}{c}\text { Perumahan } \\
\text { Cikutra } \\
\text { Highland }\end{array}$ & $\mathrm{V}$ & $\mathrm{v}$ & $\mathrm{V}$ & - & $\mathrm{V}$ & - & 4 & Cukup memenuhi syarat \\
\hline $\begin{array}{l}\text { Perumahan } \\
\text { Pasir Impun } \\
\text { Valley }\end{array}$ & $\mathrm{V}$ & $\mathrm{V}$ & - & V & - & - & 3 & Cukup memenuhi syarat \\
\hline
\end{tabular}

Keterangan:

$\begin{array}{ll}\text { JA } & \text { : Jalur Akses } \\ \text { RTH } & \text { : Ruang Terbuka Hijau } \\ \text { PL } & \text { : Penataan Lingkungan } \\ \text { BG } & \text { : Brandgang } \\ \text { SAP } & \text { : Sumber Air Pemadam } \\ \text { AP } & \text { : Alat Pemadam }\end{array}$

(Sumber: Penulis, 2017) 
Pada kriteria proteksi Pasif, jalur akses (JA) yang dimaksud mencakup aspek letak akses, lebar akses dan kondisi jalur akses dan perkerasan. Penataan Lingkungan (PL) yang dimaksud mencakup letak perumahan dalam suatu lingkungan, perencanaan keamanan, jarak dan antar bangunan. Brandgang (BG) dan ruang terbuka hijau (RTH) yang dimaksud adalah mengenai keberadaannya di perumahan. Sedangkan pada kriteria proteksi Aktif, sumber air pemadam (SAP) yang dimaksud adalah keberadaan instalasi hydran dan alat pemadam (AP) berupa APAR.

Berdasarkan nilai rata-rata yang diperoleh dari seluruh objek perumahan yang diteliti, dapat disimpulkan bahwa ternyata sebagian besar perumahan cukup memenuhi syarat proteksi kebakaran, terutama dari proteksi pasif. Dari enam perumahan yang diteliti, ada lima perumahan yang cukup memenuhi syarat, yaitu Cigadung Hills, La Casturi, Golden Imperial, Cikutra Highland, dan Pasir Impun Valley. Hanya satu perumahan yang belum memenuhi syarat, yaitu perumahan Cigadung Greenland.

Aplikasi proteksi risiko kebakaran di perumahan memang belum sempurna. Meskipun terdapat perbedaan konteks antara Bandung dan Jakarta, namun terdapat beberapa kesamaan risiko, dampak, dan penyebab kebakaran dengan kondisi di Jakarta. Jika diperhatikan dari tabel tersebut, dan disamakan dengan hasil analisa dari peraturan perundang-undangan, dapat dipahami bahwa banyak risiko kebakaran, terutama dari sisi proteksi pasif dan manajemen penanggulangan risiko kebakaran yang luput dari peraturan. Karena itu, penerapannya proteksi risiko kebakaran pada perumahan menjadi tidak maksimal. Hal ini ditambah lagi dengan lambatnya penerbitan aturan konkrit dari Peraturan Walikota yang mengaburkan aturan mengenai keberlakuan Perda mengenai proteksi kebakaran.

Hal lain yang ditemukan adalah rendahnya pengetahuan warga mengenai proteksi risiko kebakaran di perumahan. Menurut wawancara kepada Mardi Uripto (2015), staf bidang pemadaman Dinas Pemadam Kebakaran Kota Bandung, minimnya dana sosialisasi menyebabkan penyebaran pengetahuan mengenai proteksi risiko kebakaran menjadi tersendat. Dalam satu tahun, tak semua kecamatan dapat memperoleh sosialisasi. Pun dalam sekali sosialisasi, yang hadir hanya perwakilan dari tiap kelurahan, bukan warga secara keseluruhan. Pihak akademisi pun tak semuanya merasa perlu mengetahui mengenai proteksi risiko kebakaran sehingga berujung pada ketidaktahuan mengenai hal ini.

Kontraktor dan perencana nampaknya tak luput dari andil terhadap kurangnya aplikasi proteksi risiko kebakaran di perumahan. Meskipun tak semua kontraktor dan perencana mengabaikan aturan mengenai proteksi risiko kebakaran, kebanyakan memilih menitikberatkan kepada keuntungan ekonomis dibandingkan keselamatan. Hal ini dapat dicontohkan melalui pilihan keberadaan brangang, luasan area terbuka, ataupun lebar jalan.

Dapat disimpulkan bahwa, peningkatan proteksi risiko kebakaran memerlukan kontribusi yang terintergrasi antara pemerintah sebagai pengampu kebijakan, kontraktor dan perencana sebagai pelaksana kebijakan, dan warga sendiri untuk membentuk kemandirian. Ketiganya perlu menyadari pentingnya hal ini sehingga kerjasama dapat terjalin baik.

\section{Referensi}

Badan Pusat Statistik kota Bandung. (2013). Kota Bandung dalam Angka Tahun 2014. Website from http://bandungkota.bps.go.id/publikasi/kota-bandung-dalam-angka-tahun-2014

Fatmawati, Ratri. (2009). Audit Keselamatan Kebakaran di GedungPT. X Jakarta. FKM, Jakarta, Universitas Indonesia. Website from http://lib.ui.ac.id/file?file=digital/125291-S-5708-Audit\%20keselamatanLiteratur.pdf

Fire and Resque Servive. (2010). A Guide to Fire Safety Standards for Residential Properties in Bedfordshire. Based on LACORS National Standards for HMOs and CLG Fire Safety Risk Assessment Guide - Sleeping Accommodation

Keputusan Menteri Negara Pekerjaan Umum Nomor 10/KPTS/2000. (2000). Ketentuan Teknis Pengamanan terhadap Bahaya Kebakaran pada Bangunan Gedung dan Lingkungan

Keputusan Walikota Bandung nomor 1484 tahun 2003. (2003). Petunjuk Pelaksanaan Pencegahan dan Penanggulangan Bahaya Kebakaran.

Mantra, Ida Bagus Gedhe Wirawibawa. (2005). Kajian Penanggulangan Bahaya Kebakaran pada Perumahan Sarijadi, Bandung (Sebuah Kajian Pendahuluan di Perumahan Sarijadi, Bandung).

Peraturan Daerah Kota Bandung Nomor 07 tahun 2013. (2013). Penyediaan, Penyerahan, dan Pengelolaan Prasarana, Sarana, dan Utilitas Perumahan dan Permukiman

Peraturan Daerah Kota Bandung Nomor 15 tahun 2001. (2001). Pencegahan dan Penanggulangan Bahaya Kebakaran.

Peraturan Daerah Kota Bandung No 12 tahun 2012. (2012). Pencegahan Penanggulangan Bahaya Kebakaran dan Retribusi Alat Pemadam Kebakaran

Prasetyo, Budi. (2014).Setidaknya Ada 74 Ribu Lokasi di Kota Bandung Rawan Kebakaran. Website from: http://m.tribunnews.com/regional/2014/10/03/setidaknya-ada-74-ribu-lokasi-di-kota-bandung-rawankebakaran

10 jurnal arsitektur ZONASI : Vol. 2 No. 1, Februari 2019 
Riswan, Oris. (2013). Tahun ini 134 Kebakaran Terjadi di Bandung. Website from: http://daerah.sindonews.com/read/821874/21/tahun-ini-134-kebakaran-terjadi-di-bandung1388379062

Sagala, Saut, et al.(2013). Analisis Upaya Pencegahan Bencana Kebakaran di Pemukiman Padat Perkotaan Kota Bandung, Studi Kasus Kelurahan Sukahaji. Resilience Development Initiative, Working Paper Series No. 3, Desember 2013.

Sagala, Saut, et al. (2014). Perilaku dan Kesiapsiagaan Terait Kebakaran pada Penghuni Pemukiman Padat Kota Bandung. Forum Geografi, Vol. 28, No. 1, Juli 2014: 1 - 20.

Sayuti, Ahmad. (2014). Nenek Tua Tewas dalam Kebakaran di Karawita. Website from: http://www.inilahkoran.com/read/ detail/2081797/nenek-tua-tewas-dalam-kebakaran-di-karawitan.

Simanjuntak, Manlian Ronald Adventus. (2013). Desain Keselamatan Terhadap Risiko Kebakaran (Fire Safety Environtment Area) pada Lingkungan Perumahan \& Permukiman di DKI Jakarta.

Undang-Undang Republik Indonesia Nomor 4 tahun 1992 tentang Perumahan dan Pemukiman

Singapore Housing Policy. (2015)

Siswadi, Anwar. (2014) Hampir Setiap Hari Bandung Kebakaran. Website from: http://www.tempo.co/read/news/2014/10/13/058613975/Hampir-Setiap-Hari-Bandung-Kebakaran

(2014) 95 Persen Penyebab Kebakaran Kota Bandung, Korsleting Listrik. Website from: http://nasional.republika.co.id/berita/nasional/pemprov-jabar/14/10/16/ndixek-95-persen-penyebabkebakaran-kota-bandung-korsleting-listrik

(2013) Ini Titik Rawan Kebakaran di Kota Bandung. Website from: http://jabartoday.com/headline/2013/06/05/1908/13282/ini-titik-rawan-kebakaran-di-kotabandung\#.VM_7I6wXdk 